\title{
Identification of a 6-month-old baby with a combination of WAGR and Potocki-Shaffer contiguous deletion syndromes by SNP array testing
}

Yan Meng ${ }^{1,2,3,4}$, Jun Yang ${ }^{1,2,3,4}$, Chan Tian ${ }^{1,2,3,4^{*}+}$ and Jie Qiao ${ }^{1,2,3,4,5,6^{*+}}$

\begin{abstract}
WAGR 11 p13 deletion syndrome is associated with abnormalities including (W) ilms tumor, (A) niridia, (G) enitourinary abnormalities, and growth and mental (R) etardation (WAGR). Potocki-Schaffer syndrome is a contiguous gene syndrome associated with deletions in 11 p11.2, principal features of which are multiple exostoses, parietal foramina development delay, mental retardation, and facial dysmorphism. In some cases, males may have enlarged anterior fontanels and genital abnormalities. Each of these syndromes is very rare. Here we report a patient with both WAGR and Potocki-Shaffer syndromes who presented with aniridia, nystagmus, macular dysplasia, enlarged anterior fontanel, mental retardation, ptosis, low-set ears, micrognathia, and atrial septal defect at 6 months old. SNP array revealed a large (26.25 Mb)deletion: arr[hg19]11p15.1p11.2(18742043-44991839)× 1. Genetic testing allowed for diagnosis of this patient at a very young age. In addition to the postnatal phenotype of the patient, we found one prenatal symptom of these syndromes is oligohydramnios, which when present might indicate advanced prenatal diagnosis. This made the possibility of prenatal diagnosis for these syndromes.
\end{abstract}

Keywords: WAGR syndrome, Potocki-Schaffer syndrome, Combined deletion syndrome, 11p15.1p11.2 deletion, Oligohydramnios

\section{Introduction}

WAGR syndrome (OMIM \#194072), first described by Miller in 1964 [1], is a rare microdeletion syndrome that predisposes children to the develop Wilms' tumor (nephroblastoma), aniridia, genitourinary anomalies, and intellectual disability (mental retardation). The prevalence of WAGR syndrome ranges from 1 in 500,000 to 1 million. The cytogenetic basis of WAGR syndrome, a deletion of 11p13, was recognized by Riccardi et al. in 1978 [2]. The deletion fragment (GRCh37: 31806339-

\footnotetext{
*Correspondence: jie.qiao@263.net; tianchan_cdc@126.com

${ }^{\dagger}$ Jie Qiao and Chan Tian contributed equally to this work.

${ }^{1}$ Center for Reproductive Medicine, Department of Obstetrics and Gynecology, Peking University Third Hospital, Beijing 100191, China Full list of author information is available at the end of the article
}

$32457087650.75 \mathrm{~kb}$ ) varies greatly from 1 to $26.5 \mathrm{Mb}$ (https://decision.sanger.ac.uk/syndrome/35 $\times$ overview), and always includes four OMIM genes: PAX6, RCN1, WT1, and WT1-A. Mutations in PAX6 (OMIM: 607108) and WT1 (OMIM: 607102) genes were confirmed to cause developmental disorders. For example, mutations in PAX6 may cause keratitis hereditary (OMIM:148190), coloboma of optic nerve (OMIM:120430), Peters anomaly (OMIM: 604229), foveal hypoplasia (OMIM:136520), bilateral optic nerve hypoplasia (OMIM: 165550), aniridia (OMIM:106210), or aniridia cerebellar ataxia and mental deficiency (OMIM: 206700), and PAX6 also has a haploinsufficient effect; mutations in WT1 can cause Denys-Drash Syndrome (OMIM: 194080), Frasier syndrome (OMIM:136680), nephrotic syndrome, type 4

(c) The Author(s). 2020 Open Access This article is licensed under a Creative Commons Attribution 4.0 International License, which permits use, sharing, adaptation, distribution and reproduction in any medium or format, as long as you give appropriate credit to the original author(s) and the source, provide a link to the Creative Commons licence, and indicate if changes were made. The images or other third party material in this article are included in the article's Creative Commons licence, unless indicated otherwise in a credit line to the material. If material is not included in the article's Creative Commons licence and your intended use is not permitted by statutory regulation or exceeds the permitted use, you will need to obtain permission directly from the copyright holder. To view a copy of this licence, visit http://creativecommons.org/licenses/by/4.0/ The Creative Commons Public Domain Dedication waiver (http://creativecommons.org/publicdomain/zero/1.0/) applies to the data made available in this article, unless otherwise stated in a credit line to the data. 
(OMIM: 256370), Wilms tumor, type 1 (OMIM: 194070), Meacham syndrome (OMIM: 608978), and mesothelioma, somatic (OMIM: 156240). The eponymous Potocki-Shaffer syndrome (PSS, OMIM: 601224), a rare microdeletion syndrome caused by haploinsufficiency of genes located on 11p11.2p12(GRCh37: $43994800-46052450,2.06 \mathrm{Mb}$ ), was described for the first time in 1996 [3]. The main phenotypes of PSS include developmental delay, craniofacial abnormalities, mental retardation, multiple exostoses, parietal foramina, enlarged anterior fontanel, ophthalmologic anomalies, and genital abnormalities in males. PSS is inherited in an autosomal dominant manner, and the size of the deletion segment is variable with a minimum content of $2.06 \mathrm{Mb}$ (GRCh37: 31806339-32457087, 2.06 Mb)(https://decipher. sanger.ac.uk/syndrome/34\#overview). This area includes 14 OMIM genes. Among them, EXT2 (OMIM: 608210) is responsible for multiple exostoses (OMIM:133701) [4], and ALX4 (OMIM: 605420) causes parietal foramina (OMIM: 609597) [5]. Here we document the diagnosis of a female infant suffering from WAGR and PSS concurrently; her heterozygous deletion includes the core genes and she displays a partial phenotype of each syndrome. At 5 months, she was diagnosed as the youngest case reported so far. We also summarize her prenatal stage phenotype to provide crucial indications for prenatal testing and diagnosis for other possible patients.

\section{Case description}

A 4-month-old female infant was referred to the genetic clinic for aniridia and an enlarged anterior fontanel during November 2019. She was the first child of nonconsanguineous parents, both of whom are now 33 years old. The mother underwent surgical tumor removal due to mucinous cystadenoma of the right ovary at the age of 27. Simultaneously, she suffered from polycystic ovarian syndrome (PCOS) and subclinical hypothyroidism. Because of the PCOS, the infant was conceived through in vitro fertilization and embryo transfer (IVF-ET). Euthyrox was given orally before pregnancy, and thyroid function was well-controlled. A genetic karyotype analysis of both parents was done prior to in vitro fertilization (IVF), and results were normal.

The mother of the patient had a routine prenatal examination during pregnancy. The ultrasound examination at 12 weeks of gestation revealed no major structural abnormalities in the fetus, and the thickness of nuchal translucency (NT) was normal. Noninvasive prenatal testing (NIPT) at $14^{+5}$ weeks showed no abnormalities. There was a mild reduction in the amount of amniotic fluid (AF) observed at 28 weeks of gestation, but no other abnormal findings were identified at this time. Percutaneous umbilical blood sampling was recommended to the mother to exclude possible genetic disorders, but she declined. The amount of AF was monitored regularly during mid-late gestation (weeks 24 through 39), and results are shown in Fig. 1. The amount of AF was reduced than normal between 28 and 30 weeks and at 38 weeks of gestation. The baby was born at 40 weeks of gestation. Her birth weight was $2820 \mathrm{~g}$, height was $49 \mathrm{~cm}$, head circumference $(\mathrm{HC})$ was $31.5 \mathrm{~cm}$, and Apgar score was 10; all parameters were in normal range.

After delivery, however, due to "poor response", the infant was transferred to the neonatal intensive care unit. After a routine blood test showed that the white blood cells (WBC) increased to $33.7 \times 10^{9} / \mathrm{L}$ and granulocytes were at $72.8 \%$, antibiotic treatment was given. Physical examination showed that the anterior fontanelle was $2.5 \times 2.5 \mathrm{~cm}$, full, and accessible to the bone seam, and the posterior fontanelle was at $2 \times 2 \mathrm{~cm}$ and not closed; thyroid function appeared to be normal; ultrasound scan showed normal liver, gallbladder, pancreas, spleen and kidney; normal MRI brain scan and diffusion-weighted brain imaging was reported; echocardiography showed that the atrial septal defect (central

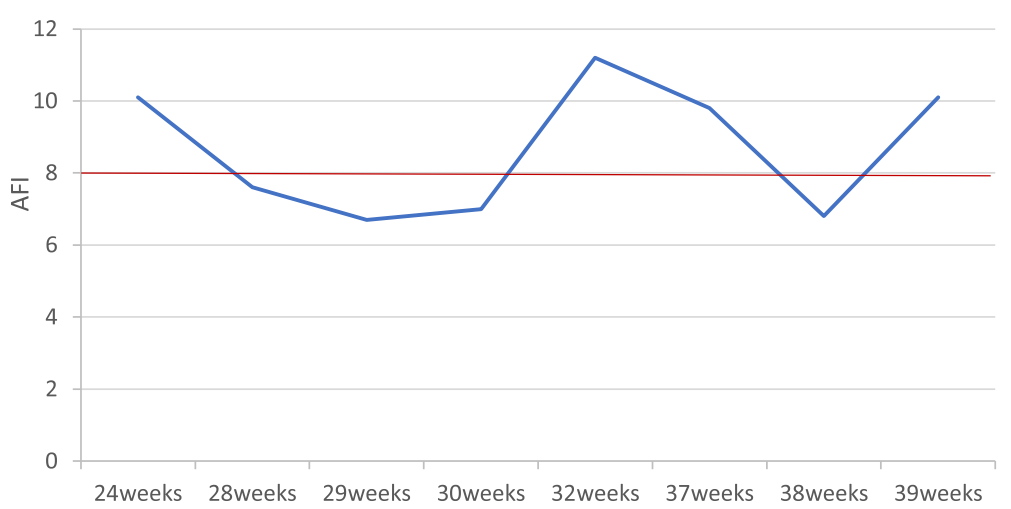

Fig. 1 The amniotic fluid index (AFI) in the mid-late stage of gestation. The amount of amniotic fluid in the mid-late stage of gestation. The mother's amniotic fluid was reduced beginning from the 28th week of gestation. (AFI > 8 is normal, AFI between 5 and 8 is oligohydramnios) 
type) was $2 \mathrm{~mm}$; and the newborn hearing screening was in the normal range. After 12 days of antibiotic treatment, the WBC decreased to $9.1 \times 10^{9} / \mathrm{L}$, and the granulocytes decreased to $34.6 \%$. The infant was then discharged from the hospital.

Signs of bilateral aniridia and ptosis were noticed by physicians at Xi'an Angel Women's \& Children's Hospital when the infant was 6 weeks old. Developmental delays were observed at 3 months old with manifestations of great motor retardation. At 4 months old, she was diagnosed with aniridia, ptosis, macular dysplasia, nystagmus, low set ears, and an enlarged anterior fontanel. Genetic examination was recommended. On November 6, 2019, SNP array analysis was performed in our hospital, and arr [hg19]11p15.1p11.2(18742043-44,991,839) xl $(26.25 \mathrm{Mb})$ was detected. The molecular diagnosis confirmed that the patient had both WAGR and Potocki-Schaffer syndromes.

The patient is now 6 months old with normal body length, weight, and head circumference. After intensive pediatric physical therapy, she can raise her head but cannot sit. Her intellectual ability is equivalent to that of a 3-month-old. Physical examination revealed an enlarged anterior fontanel, aniridia, ptosis, macular dysplasia, nystagmus, low set ears, rough face, micrognathia, and atrial septal defect. The growth stage-based development and phenotype assessments are shown in Table 1.

\section{Discussion}

We present a patient who was diagnosed by genetic testing with both WAGR and Potocki-Schaffer syndromes at 5 months; to date she is the youngest diagnosis of such a combination. She presented phenotypes including intellectual disability, aniridia, nystagmus, low-set ears, ptosis, macular dysplasia, rough face, micrognathia, atrial septal defect, developmental delay, enlarged anterior fontanel, and atrial septal defect. The only perinatal indication was decreased amniotic fluid.

WAGR syndrome is defined as a genetic syndrome in which there is a predisposition to aniridia, Wilms tumor, genitourinary anomalies, and intellectual disability. Some individuals may also present with mental disorders and obesity. A combination of two or more of the aforementioned clinical features is required for an individual to be diagnosed with WAGR syndrome. The feature invariably present in all documented cases is aniridia [6]. Aniridia can be found in infancy and is often accompanied by late cataracts, glaucoma, and corneal abnormalities. Wilms tumor is usually bilateral and occurs early, and renal dysplasia is also common. Children with WAGR syndrome should receive regular (3-4 monthly) renal surveillance for Wilms tumor until at least the age of 6-8 years and thereafter should remain under some renal follow-up due to the risk of late onset nephropathy (experienced by $40 \%$ of patients over the age of 12 years). Genitourinary anomalies include cryptorchidism, hypospadias, and ambiguous sexual organs. Females with WAGR syndrome may have streak ovaries, which can increase their risk for gonadoblastoma, and malformations of the vagina and/or uterus may also be present (https://decipher.sanger.ac.uk/syndrome/35\#overview). Given the myriad complications and risks, we will continue to monitor this patient.

WAGR and Potocki-Schaffer syndromes are caused by deletions of genes located on chromosome 11. By searching in DECIPHER (https://decipher.sanger.ac.uk), we confirmed that our patient has the second largest p13 deletion on chromosome 11 after a case with a $134.05 \mathrm{Mb}$

Table 1 Growth, development and phenotype of the patient

\begin{tabular}{|c|c|c|c|c|c|c|c|c|}
\hline Age & Weight (kg) & Height (cm) & $\begin{array}{l}\mathrm{HC} \\
(\mathrm{cm})\end{array}$ & Parietal foramina & $\begin{array}{l}\text { Abnormality of } \\
\text { ophthalmologic }\end{array}$ & Ear & Face & Development \\
\hline At birth & 2.85 & 49.0 & 31.5 & $\begin{array}{l}\text { Anterior fontanelle } \\
2.5 \times 2.5 \mathrm{~cm} \\
\text { Posterior fontanelle } \\
2.0 \times 2.0 \mathrm{~cm} \\
\text { Accessible to the bone } \\
\text { seam }\end{array}$ & Aniridia Ptosis & Low-set ears & Gothic arch & \\
\hline 3 months & 5.40 & 56.4 & 37.0 & $\begin{array}{l}\text { Anterior fontanelle } \\
>5 \times 5 \mathrm{~cm}\end{array}$ & Aniridia Ptosis & Same as up & Same as up & $\begin{array}{l}\text { Developmental delay } \\
\text { High tension of limb } \\
\text { muscles }\end{array}$ \\
\hline 4 months & 6.40 & 59.2 & 38.0 & $\begin{array}{l}\text { Anterior fontanelle } \\
>5 \times 5 \mathrm{~cm}\end{array}$ & $\begin{array}{l}\text { Aniridia Ptosis } \\
\text { Nystagmus }\end{array}$ & Same as up & Same as up & $\begin{array}{l}\text { Developmental delay } \\
\text { High tension of limb } \\
\text { muscles } \\
\text { High back flexion } \\
\text { tension }\end{array}$ \\
\hline 5 months & 6.90 & 61.6 & 39.4 & $\begin{array}{l}\text { Anterior fontanelle } \\
>5 \times 5 \mathrm{~cm}\end{array}$ & $\begin{array}{l}\text { Aniridia Ptosis } \\
\text { Nystagmus }\end{array}$ & Same as up & $\begin{array}{l}\text { Gothic arch } \\
\text { Micrognathia }\end{array}$ & $\begin{array}{l}\text { Developmental delay } \\
\text { Limited abduction of } \\
\text { both legs } \\
\text { Great motor retardation }\end{array}$ \\
\hline 6 month & 7.30 & 63.1 & 41.0 & $\begin{array}{l}\text { Anterior fontanelle } \\
>5 \times 5 \mathrm{~cm}\end{array}$ & $\begin{array}{l}\text { Aniridia Ptosis } \\
\text { Nystagmus }\end{array}$ & Same as up & Same as up & $\begin{array}{l}\text { Developmental delay } \\
\text { Great motor retardation }\end{array}$ \\
\hline
\end{tabular}


mosaic deletion (DECIPHER ID: 286222). Ten other cases with shorter deletions are (by DECIPHER ID number): 392823(20.55 Mb), 394119(20.55 Mb), 394138(20.55 Mb), 394162(17.80 Mb), 286003(15.14 Mb), 290351(15.55 Mb), 394905(17.80 Mb), 394959(20.55 Mb), 394991(17.80 Mb) and $395910(22.70 \mathrm{Mb})$. The phenotypic variability among these cases is high. Some patients already exhibit the phenotypes caused by the deletion of key pathogenic genes (ALX4, EXT2, PAX6, and WT1), and others do not. Deleted fragments containing the $B N D F, E 2 F 8$ and KCNA4 genes found in the current case were not detected in previously reported cases. Therefore, unique phenotypes observed in our patient may appear in other patients in the future. The details of previously reported cases are shown in Supplementary Table 2.

In addition, two similar cases and an atypical case were reported in the literature that are not in DECIPHER (Table 2). Case 1, reported in 1995, was a 26year-old man with WAGR syndrome and multiple exostoses. Chromosome analysis showed an abnormal male karyotype 46,XY,del(11)(p11.2p14.2) with an interstitial deletion in the short arm of chromosome 11. A deletion of the WT1 gene was confirmed using FISH probes [7]. Case 2, reported in 2005, was a 25-year-old woman with WAGR and Potocki-Shaffer syndromes. Conventional high-resolution R-banding found a deletion in the proximal short arm of chromosome 11 homologue with breakpoints described as del(11)(p11.2p14.1); the deletion was then confirmed by FISH [8]. Due to the limitations of genetic technology when these cases were discovered, the exact chromosome location of the deleted segments were not available, so we were unable to analyze in detail the associations between the deleted genes and phenotypes. Case 3, reported in 2009, was a 15 -year-old boy with an $11 \mathrm{p}$ microdeletion including WT1 but not PAX6. Cytogenetic analysis showed a deletion on $11 \mathrm{p}$ that was further characterized using FISH and MLPA analyses. The deletion (11p13-p12), located between the deletions associated with WAGR and Potocki-Shaffer syndromes, had a maximum size of 8.5 $\mathrm{Mb}$ and encompasses 44 genes. The distal and proximal breakpoints were mapped [9]. While the exact chromosome location of the deletion was obtained in this case, the diagnosis methods used (karyotype analysis, FISH, and MLPA) are tedious and time-consuming.

For our patient, the deletion size of $11 \mathrm{p}$ is $26.25 \mathrm{Mb}$ and includes 138 genes, 73 of which are OMIM genes. ALX4, EXT2, PAX6 and WT1, all of which affect development, are the key genes for the pathogenesis of WAGR and Potocki-Schaffer syndromes. Other altered genes in this patient that may cause diseases due to haploinsufficiency include BDNF, CAPRIN1, KCNA4, LGR4, and SLC1A2. Recently, Xu et al. reported that deletion of SLC1A2, PRRG4, and BDNF may be involved in abnormal psychological development [10] (e.g., early epileptic encephalopathy). Andrey V. et al. reported that deletion of the PRRG4 gene is related to autism in patients with WAGR, and deletion of both WT1 and $L M O 2$ genes is increases the risk of developing Wilms tumor [11]. The phenotypes for KCNA4 deficiency include microcephaly, cataracts, impaired intellectual development, and dystonia with abnormal striatum (OMIM: 618214). An insufficient dose of LGR4 can lead to low bone mineral density in adults (OMIM: 615311). In the deletion area, some genes were morbid and can cause the phenotype, and some genes were not. We described some genes that can cause phenotype and other genes were summarized in in Supplementary Table 1. The patient was diagnosed at 5 months old. Her current phenotypes are intellectual disability, aniridia, nystagmus, low-set ears, ptosis, macular dysplasia, rough face, micrognathia, atrial septal defect, developmental delay, enlarged anterior fontanel, and atrial septal defect. According to the

Table 2 Summary of similar cases reported in the literature

\begin{tabular}{|c|c|c|c|c|}
\hline $\begin{array}{l}\text { Case } \\
\text { number }\end{array}$ & $\begin{array}{l}\text { Deletion and the } \\
\text { breakpoints }\end{array}$ & $\begin{array}{l}\text { Age at last clinical } \\
\text { assessment }\end{array}$ & Phenotypes & References \\
\hline Case 1 & del(11)(p11.2p14.2) & 26 years & $\begin{array}{l}\text { Bilateral aniridia, Lacunae in the left parietal, Large fontanelle, } \\
\text { Bilateral buphthalmos, Glaucoma, Lens opacities, Hypospadias, } \\
\text { Undescended testes, Small penis at } 2 \text { months; Wilms'tumour at } \\
2 \text { years; Glomerulonephritis, Multiple exostoses, Hypertension, } \\
\text { Mental retardation at } 4 \text { years and older. }\end{array}$ & [7] \\
\hline Case 2 & $\operatorname{del}(11)(p 11.2 p 14.1)$ & 25 years & $\begin{array}{l}\text { Aniridia, Ptosis, Low set ears, Flat malar areas, Micrognathia at } \\
3 \text { months; Left kidney tumor at } 15 \text { months; Multiple exostoses } \\
\text { at } 6 \text { years; Cataract at } 7 \text { years; Mammary hypertrophy, Severe } \\
\text { obesity at } 10 \text { years; Horizontal nystagmus, Bilateral aphakia, } \\
\text { Complete bilateral aniridia with neovascularization, Scars of } \\
\text { corneal ulcer, Corneal opacities, Ocular hypertension, Hypertension, } \\
\text { Proteinuria, Mild to moderate mental retardation, Disturbances, } \\
\text { Obsessive, Hyperphagia, Temper tantrums, Intolerance to frustration, } \\
\text { Exostoses, Small foramina. }\end{array}$ & [8] \\
\hline $\begin{array}{l}\text { Case } 3 \text { (atypia no } \\
\text { PAX6 deletion) }\end{array}$ & del(11)p13-p12 & 15 years & $\begin{array}{l}\text { Cataract, Astigmatism and myopia in the right eye, Facial deformities, Bilateral ptosis, } \\
\text { Nasal bridge depression, Ear fold, Maxillary malocclusion, } \\
\text { Cryptorchidism, Hypospadias, Postoperative testicular atrophy, Mild to } \\
\text { moderate mental retardation, Epilepsy starts at the age of } 9 .\end{array}$ & [9] \\
\hline
\end{tabular}


previously reported phenotypes of these syndromes and the functions of the associated deleted genes, we anticipate that some phenotypes, such as glaucoma, cataract, Wilms tumor, multiple exostoses, strabismus, autism, dystonia with abnormal striatum, early epileptic encephalopathy, or other mental problems, may occur later in her life. A depressed nasal bridge, streak ovaries, malformations of the uterus, diabetes, and low bone mineral density in adulthood might also appear in the future. Therefore, we suggest follow-ups to monitor the patient for these potential phenotypes as early as possible so that she can receive appropriate treatments in a timely manner. Our report describes a unique case that will help doctors enhance their understanding of this disease.

To improve the perinatal identification of these extremely rare genetic disorders, we searched the literature for prenatal diagnosis indications. We found that only one article reported these characteristics for WAGR syndrome during the prenatal stage [12]. The mother was diagnosed with gestational diabetes at 16 weeks of gestation. The ultrasonographic examination at 29 weeks of gestation found borderline bilateral ventriculomegaly, absent corpus callosum, absent cavum septum pellucidum, large kidneys, and mildly reduced amniotic fluid volume. For further diagnosis, she opted for fetal brain MRI and amniocentesis followed by microarray analysis, and WAGR syndrome was diagnosed before the late termination of pregnancy. Similarly, in our currently reported case, we detected mildly reduced amniotic fluid. Genetic consultation was provided and amniocentesis was recommended. Unfortunately, the mother declined to undergo amniocentesis and we missed the opportunity for prenatal diagnosis. No abnormalities were indicated by other prenatal tests. Oligohydramnios is the common prenatal feature and an indication of these syndromes in both of these cases. It is very important that women with reduced amniotic fluid undergo prenatal diagnosis after prenatal screening. Doctors should continue to collect and report data during the prenatal stage to provide clues for early diagnosis.

\section{Supplementary information}

Supplementary information accompanies this paper at https://doi.org/10. 1186/s41065-020-00132-2.

Additional file 1: Table S1. The genes that don't affect development but cause diseases due to haploinsufficiency.

Additional file 2: Table S2. Cases including core genes of two syndromes.

\section{Abbreviations}

OMIM: Online Mendelian Inheritance in Man; IVF-ET: In Vitro Fertilization and Embryo Transfer (IVF-ET); PCOS: Polycystic Ovary Syndrome (PCOS); NIPT: Noninvasive Prenatal Testing (NIPT); NT: Nuchal Translucency (NT); AF: Amniotic Fluid (AF); HC: Head Circumference (HC); AFI: Amniotic Fluid Index (AFI); WBC: White Blood Cells (WBC)

\section{Acknowledgements}

Not applicable.

\section{Authors' contributions}

All authors participated in the design of the case report and coordination and helped to draft the manuscript. All authors read and approved the final manuscript.

\section{Funding}

National Key R\& D Program of China 2016 YFC1000500 2016 YFC1000501.

\section{Availability of data and materials}

All data generated or analyzed during this study are included in this published article.

\section{Ethics approval and consent to participate}

This study was conducted in accordance with the Declaration of Helsinki and was approved by the Medical Ethics Committee of Peking University Third Hospital.

Consent for publication

Written informed consent was provided by the patient's parents.

\section{Competing interests}

The authors declare that they have no competing interests.

\section{Author details}

${ }^{1}$ Center for Reproductive Medicine, Department of Obstetrics and Gynecology, Peking University Third Hospital, Beijing 100191, China. ${ }^{2}$ Nationa Clinical Research Center for Obstetrics and Gynecology, Beijing 100191,

China. ${ }^{3}$ Key Laboratory of Assisted Reproduction (Peking University), Ministry of Education, Beijing 100191, China. ${ }^{4}$ Beijing Key Laboratory of Reproductive Endocrinology and Assisted Reproductive Technology, Beijing 100191, China. ${ }^{5}$ Beijing Advanced Innovation Center for Genomic, Beijing 100871, China. ${ }^{6}$ Peking-Tsinghua Center for Life Sciences, Peking University, Beijing 100871, China.

Received: 28 February 2020 Accepted: 14 April 2020

Published online: 23 May 2020

\section{References}

1. Miller RW, Fraumeni JF Jr, Manning MD. Association of Wilms's tumor with aniridia, hemihypertrophy and other congenital malformations. N Engl J Med. 1964;270:922-7.

2. Riccardi VM, Sujansky E, Smith AC, Francke U. Chromosomal imbalance in the Aniridia-Wilms' tumor association: $11 \mathrm{p}$ interstitial deletion. Pediatrics. 1978:61:604-10.

3. Potocki $L$, Shaffer LG. Interstitial deletion of 11(p11.2p12): a newly described contiguous gene deletion syndrome involving the gene for hereditary multiple exostoses (EXT2). Am J Med Genet. 1996;62:319-25.

4. Stickens D, Clines G, Burbee D, et al. The EXT2 multiple exostoses gene defines a family of putative tumour suppressor genes. Nat Genet. 1996; 14(1):25-32.

5. Wu YQ, Badano JL, McCaskill C, Vogel H, Potocki L, Shaffer LG. Haploinsufficiency of ALX4 as a potential cause of parietal foramina in the 11 11.2 contiguous gene-deletion syndrome. Am J Hum Genet. 2000;67(5): 1327-32.

6. Bartsch $\mathrm{O}$, Wuyts $\mathrm{W}$, Wet $\mathrm{VH}$, et al. Delineation of a contiguous gene syndrome with multiple exostoses, enlarged parietal foramina, craniofacial dysostosis, and mental retardation, caused by deletions in the short arm of chromosome 11. Am J Hum Genet. 1996;58:734-42.

7. Mc Gaughran JM, Ward HB, Evans DG. WAGR syndrome and multiple exostoses in a patient with del(11)(p11.2p14.2). J Med Genet. 1995:32:823-4.

8. Bre mond-Gignac D, rolla JA, et al. Combination of WAGR and PotockiShaffer contiguous deletion syndromes in a patient with an 1p11.2-p14 deletion. Eur J Human Genet. 2005;13(4):409-13.

9. Gitte J Almind, Karen røndum-Nielsen, Regitze Bangsgaard, et al. 11p microdeletion including WT1 but not PAX6, presenting with cataract, mental retardation, genital abnormalities and seizures. A case report. Mol Cytogenet 2009;2:6 
10. Xu S, Han JC, Morales A, Menzie CM, Williams K, Fan Y-S. Characterization of 11p14-p12 deletion in WAGR syndrome by array CGH for identifying genes contributing to mental retardation and autism. Cytogenet Genome Res. 2008:122(2):181-7.

11. Marakhonov AV, Vasilyeva TA, Anna A, et al. LMO2 gene deletions significantly worsen the prognosis of Wilms' tumor development in patients with WAGR syndrome. Hum Mol Genet. 2019;28(19):3323-6.

12. Tezcan B, Rich P, Bhide A. Prenatal Diagnosis of WAGR Syndrome. Obstet Gyneco. 2015;2015:928585.

\section{Publisher's Note}

Springer Nature remains neutral with regard to jurisdictional claims in published maps and institutional affiliations.

Ready to submit your research? Choose BMC and benefit from:

- fast, convenient online submission

- thorough peer review by experienced researchers in your field

- rapid publication on acceptance

- support for research data, including large and complex data types

- gold Open Access which fosters wider collaboration and increased citations

- maximum visibility for your research: over $100 \mathrm{M}$ website views per year

At $B M C$, research is always in progress.

Learn more biomedcentral.com/submissions 